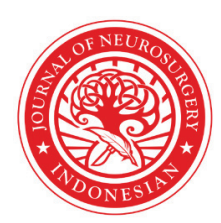

\title{
Supraorbital and supratrochlear neuralgia caused by dermoid cyst
}

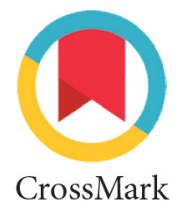

\author{
Farid Yudoyono ${ }^{1,2^{*}}$, Dewi Pratiwi ${ }^{1}$, Hendra ${ }^{1}$
}

\section{ABSTRACT}

Background: Patients with supraorbital neuralgia (SON) and supratrochlear neuralgia (STN) complain disabling pain including headaches and numbness. Previous study reported from trauma and following surgery, but our case cause by chronic suppression by frontal mass. Treatment for headaches and pain include analgesic and anticonvulsants and excision.

Objective: To present a case of SON and STN neuralgia cause by suppresion of dermoid cyst.

Methods: A Case report.
Results: A 17-year-old female patient complained of a swelling on the left forehead with an increasingly severe pain followed by numbness. CT scan revealed a $4 \mathrm{~cm}$ cyst like mass in the left frontal. Mass excision was performed on this patient. Histopathological result indicated dermoid cysts. 3 months after surgery, headache and numbness were significantly reduced.

Conclusions: SON and STN may result from a chronic suppression by dermid cyst. With mass excision, patient complaints can be minimized without complication.

Keywords: Dermoid Cyst, Headache, Numbness, Supraorbital neuralgia, Supratrochlear neuralgia

Cite This Article: Yudoyono, F., Pratiwi, D., Hendra. 2020. Supraorbital and supratrochlear neuralgia caused by dermoid cyst. Indonesian Journal of Neurosurgery 3(2): 68-70. D0I: 10.15562/ijn.v3i2.125

${ }^{1}$ Neurospine and Pain Center, Santosa Hospital Bandung Kopo, Bandung, Jawa Barat, Indonesia ${ }^{2}$ Departement of Neurosurgery, Hasan Sadikin Hospital, Faculty of Medicine, Universitas Padjadjaran, Bandung, Jawa Barat, Indonesia
*Corissponding Author: Farid Yudoyono; Neurospine and Pain Center, Santosa Hospital Bandung Kopo, Bandung, Jawa Barat, Indonesia; Departement of Neurosurgery, Hasan Sadikin Hospital, Faculty of Medicine, Universitas Padjadjaran, Bandung, Jawa Barat, Indonesia; faridspine@gmail.com

Received: 2020-04-13 Accepted: 2020-06-28 Published: 2020-08-01

\section{INTRODUCTION}

SON is a terminal branch of the sensory nerve from frontal nerve which is major branch of the trigeminal nerve of the ophthalmic division, exiting through the supraorbital foramen, supplying the front scalp eyelids, conjunctiva and frontal sinus, alongside STN. SON and STN is very vulnerable to trauma and compression for its superficial location. ${ }^{1-4}$

Dermoid cysts occurs from failure of the surface of ectoderm to separate from the developing neuroectoderm or when surface of ectoderm undergoes infolding, invagination, and fusion as the ears, eyes, and face begin to form. ${ }^{5,6}$ Pryor et al previously reported paediatric incidence of dermoid cysts, $16 \%$ occur in anterior to the frontozygomatic suture line, $61 \%$ occur in the periorbital region and midline nasal and forehead. ${ }^{78}$ Common location of dermoid cyst are the periorbital region, the frontotemporal region and the nasoglabellar region. $^{5}$

Based on International classification of headache dissorder (ICHD), SON may indicate the following symptoms: continuous chronic pain and paroxysmal. Complaints usually include tenderness in the supraorbital foramen. Since SON and STN are closely associated with each other, the classification often experiences difficulties. ${ }^{1,2,9-13}$

\section{CASE PRESENTATION}

A 17-year-old female patient complained of mass on the left forehead with an increasingly severe pain followed by numbness and headache (Figure 2 A). Tinel's sign (+). Neurological examination indicated numbness in the left frontal area. Non contrast CT scan of the brain was consistent with a 4-cm cyst-like mass with low attenuation cavity at left frontal (Figure 1). Mass excision was performed on this patient (Figure $3 \mathrm{~A}, \mathrm{~B}$ ). Histopathological result indicated dermoid cysts (Figure 3B). 3 months after surgery, headache and numbness were significantly reduced, the patient did not visit outpatient depertement after 3 months.

\section{DISCUSSION}

SON can be found in a superficial area that is prone to trauma. Previous studies have determined the causes of SON and STN, including viral infections, demyelination and trauma, while previous study reported that tumor suppression is very rare. (Table 1) The entrapment mechanism is used to analyze the cause of this case., ${ }^{2,14}$

Deeper lesions, increasing diameter and pressure of the cyst are present with bony surface thinning or notching of adjacent bone or reactive sclerotic margin or shell of dense bone. ${ }^{5,6}$

On CT image the majority had a well-demarcated 


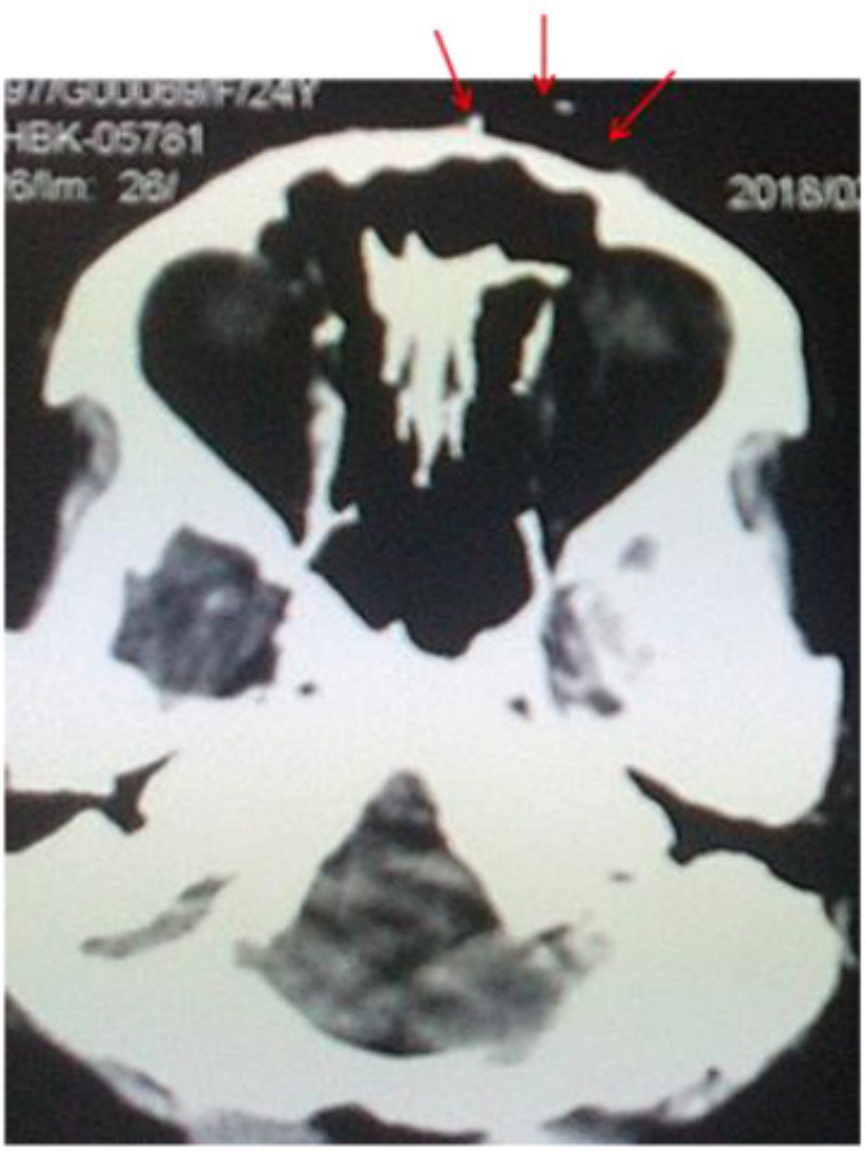

Figure 1. A Computed tomography (CT) show low attenuation similar to fat and well-demarcated left frontal mass (red arrow)

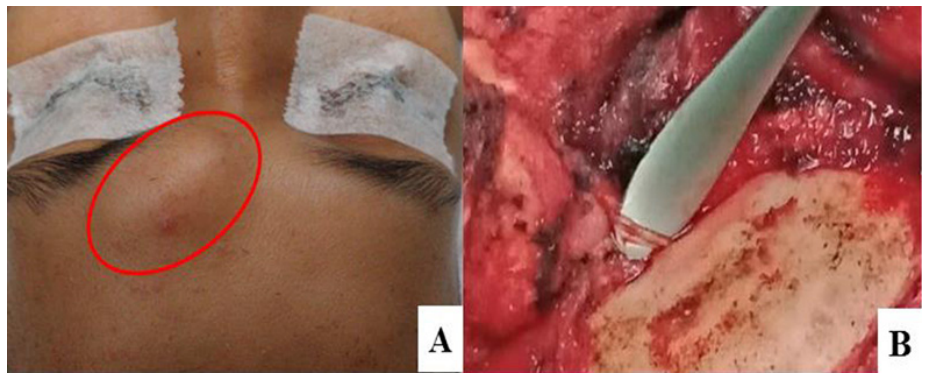

Figure 2. A) Swelling at left frontal.(red circle) B) Supraorbital nerve exit from supraorbital foramen exposed after mass excision (asterix)

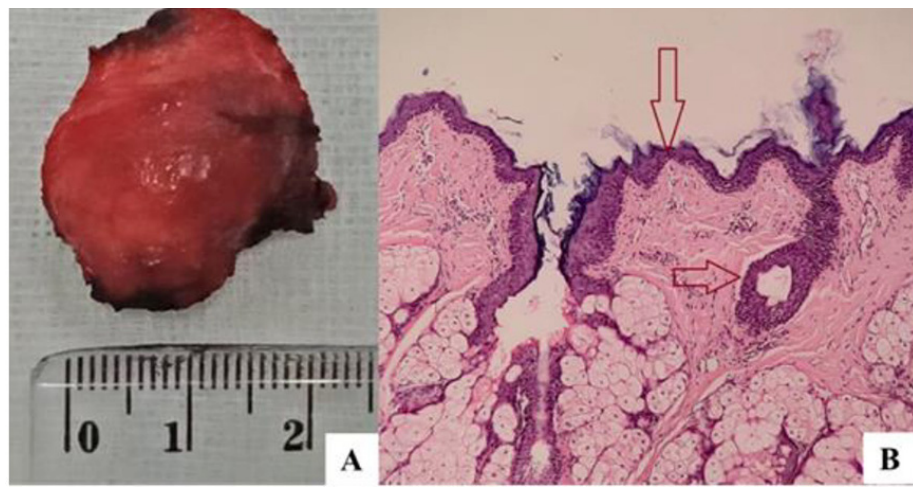

Figure 3. A) Gross specimen well-encapsulated mass $2 \mathrm{~cm}$ in diameter B) Keratinized lineage by stratified squamous epithelium (large red arrow) with keratin, skin appendages and sebaceous gland (small red arrow).

Table 1. Supraorbital and Supratrochlear mass in literature

\begin{tabular}{|c|c|c|c|c|c|c|c|c|}
\hline Case & $\begin{array}{l}\text { Age } \\
\text { (yr) }\end{array}$ & Sex & Symptoms & $\begin{array}{c}\text { Duration } \\
\text { (Mos) }\end{array}$ & $\begin{array}{c}\text { Size } \\
(\mathrm{mm})\end{array}$ & $\begin{array}{l}\text { Localiza- } \\
\text { tion }\end{array}$ & $\begin{array}{l}\text { Post operative } \\
\text { Histopathology }\end{array}$ & Journal \\
\hline 1 & 52 & Female & Painless palpable mass & 8 & $20 \times 9 \times 7$ & $\mathrm{SO}$ & $\begin{array}{c}\text { Schwanoma Antoni } \\
\mathrm{A}+\mathrm{B}\end{array}$ & Kim KS et al. $2015^{15}$ \\
\hline 2 & 46 & Female & Painless palpable mass & 2 & $8 \times 7 \times 6$ & ST & $\begin{array}{c}\text { Schwanoma Antoni } \\
\mathrm{A}+\mathrm{B}\end{array}$ & Kim KS et al. $2015^{15}$ \\
\hline 3 & 42 & Male & Pain numbness & 3-wks & $10 \times 5$ & ST & $\begin{array}{l}\text { Benign Fibrous His- } \\
\text { tiocytoma }\end{array}$ & Ito $\mathrm{T}$ et al. $2013^{16}$ \\
\hline 4 & 47 & Male & Proptosis diplopia & 3 & 2.5 & SO and ST & Cyctic Schwanoma & Feijo ED et al. $2016^{17}$ \\
\hline 5 & 41 & Female & Painless palpable mass & 15 & $2.4 \times 2$ & ST & Osteoma & Sim HS et al. $2019^{18}$ \\
\hline 6 & 14 & Male & Solid lesion & no & no & $\mathrm{SO}$ & $\begin{array}{c}\text { Schwanoma Antoni } \\
\mathrm{A}+\mathrm{B}\end{array}$ & Maciel VS et al. $2001^{19}$ \\
\hline 7 & 62 & Male & Swelling over the lid & 2 & $35 \times 25$ & SO and ST & Schwanoma Antoni A & Dilani et al. $2012^{20}$ \\
\hline
\end{tabular}

Mos = Months; $y r=$ years old $; \mathrm{mm}=$ millimeter $\mathrm{SO}=$ Supraorbital Nerve; $\mathrm{STN}=$ Supratrochlear Nerve

cyst wall with a central low-density region similar to fat. Calcifications and heterogeneity within the cyst can also be seen in race occasion. ${ }^{21}$ When dermoids cyst occur in the periorbital region, they present as swelling of soft tissue in the eyelid near the frontozygomatic suture line anterior lesions are diagnosed early childhood. Deeper orbital dermoids cyst are presenting in the teenage years and beyond. ${ }^{5}$

Management, in some cases, may include avoiding the cause before treating it with analgesic medication, NSAIDs and anticonvulsants. Nerve 
blocks and stimulation of nerves can be beneficial in some cases. Supraorbital neurolysis endoscopy and radiofrequency ablation can be used as the alternatives to reduce persistent pain. ${ }^{2}$

In this case since CT scan imaging of intracranial causes were ruled out. Etiology of the supraorbital and supratrochlear neuralgia is almost unknown, tumor suppression at its outlet may be a causative factor. The rarerity of reports to date indicates that SON and STN secondary to mass suppression is either a rare disorder or an under-recognized condition in clinical practice. ${ }^{1}$

\section{CONCLUSION}

SON and STN due to suppression of dermoid cyst are very rare. Patient complaints can be minimized within longterm follow up through mass excision.

\section{FUNDING}

No funding.

\section{CONFLICT OF INTEREST}

No conflicts of interest.

\section{AUTHOR CONTRIBUTIONS}

Conceptualization: Farid Yudoyono.

Data curation: Farid Yudoyono.

Methodology: Farid Yudoyono,

Project administration: Dewi Pratiwi

Software: Hendra

Writing - original draft: Farid Yudoyono.

Writing - review \& editing: Farid Yudoyono, Dewi Pratiwi

\section{REFERENCES}

1. Mulero P, Guerrero AL, Pedraza $M$, et al. Nontraumatic supraorbital neuralgia: A clinical study of 13 cases. Cephalalgia.2012; 32(15):1150-3. DOI: $10.1177 / 0333102412459575$

2. Asensio-Samper JM, Villanueva VL, Pérez AV, López MD, Monsalve V, Moliner S, et al. Peripheral Neurostimulation in Supraorbital Neuralgia Refractor to Conventional Therapy. Pain Practice.2008;8(2):120-24. DOI: 10.1111/ j.1533-2500.2007.00165.

3. Haładaj R, Polguj M, Topol M. Anatomical Variations of the Supraorbital and Supratrochlear Nerves: Their Intraorbital Course and Relation to the Supraorbital Margin. Med Sci Monit.2019; 25: 5201-10. doi: 10.12659/MSM.915447

4. Lee HJ, Choi KS, Won SY, Apinuntrum P, Hu KS, Kim ST et al. Topographic Relationship between the Supratrochlear Nerve and Corrugator Supercilii MuscleCan This Anatomical Knowledge Improve the Response to Botulinum Toxin Injections in Chronic Migraine? Toxins(Basel). 2015;7(7):2629-38. DOI: 10.3390/ toxins7072629

5. Pham NS, Dublin AB, Strong EB. Dermoid Cyst of the Orbit and Frontal Sinus: A Case Report.Skull Base.2010;20:275-
78. DOI: $10.1055 / \mathrm{s}-0030-1247631$.

6. Chung EM, Murphey MD, Specht CS, Cube R, Smirniotopoulos JG. Pediatric Orbit Tumors and Tumorlike Lesions: Osseous Lesions of the Orbit. RadioGraphics 2008; 28:1193-214. DOI: $10.1148 / \mathrm{rg} .276075138$

7. Kumar R, Vyas K, Jaiswal G, Bhargava A, Kundu J. Deep Orbital Dermoid Cyst Bulging into the Superior Orbital Fissure: Clinical Presentation and Management. J Ophthalmic Vis Res. 2017; 12(1): 110-12. DOI: 10.4103/2008-322X.200169

8. Pryor SG, Lewis JE, Weaver AL, Orvidas LJ. Pediatric dermoid cysts of the head and neck. Otolaryngol Head Neck Surg. 2005;132:938-42. DOI: 10.1016/j.otohns.2005.03.005.

9. Lopez K, Watson D, Hogg J. A Case of Supratrochlear, Supraorbital, and Trigeminal Neuralgia Associated with Neurofibromas of Multiple Cranial Nerves.Neurology. 2014; 8(82).

10. Evans RW, Pareja JA. Supraorbital Neuralgia. Headache.2009;49:278-81. DOI: $\quad 10.1111 / j .1526-$ 4610.2008.001328

11. Pareja JA, Pareja J, Yangüela J. Nummular headache, trochleitis, supraorbital neuralgia, and other epicranial headaches and neuralgias: the epicranias. J Headache Pain.2003; 4:125-31. DOI 10.1007/s10194-003-0046-5.

12. Pareja JA, López-Ruiz P, Mayo D, Villar-Quiles RN, Cárcamo A, Gutiérrez-Viedma Á, et al. Supratrochlear Neuralgia: A Prospective Case Series of 15 Patients. Headache. 2017 Oct;57(9):1433-42. DOI: 10.1111/ HEAD.13158.

13. Jadhav V, Patil D, Mane M. Supraorbital neuralgia. Medical Journal of Dr. D.Y. Patil University. 2014;7(2):208-10. DOI: 10.4103/0975-2870.126346

14. Sjaastad O, Stolt-Nielsen A, Pareja JA, Fredriksen TA, Vincent M . Supraorbital neuralgia. On the clinical manifestations and a possible therapeutic approach. Headache.1999;39(3): 204-12. DOI: $10.1046 / j .1526-$ 4610.1999.3903204.

15. Kim KS, Jung JW, Yoon KC, Kwon YJ, Hwang JH, Lee SY. Schwannoma of the Orbit. Arch Craniofac Surg. 2015;16(2):67-72. DOI: 10.7181/acfs.2015.16.2.67

16. Ito T, Yoshida Y, Furue M, Yamamoto O. Subcutaneous Benign Fibrous Histiocytoma Showing Nerve Involvement on the Eyebrow Region. Letters to the Editor. Acta DermatoVenereologica. 2013:1-2. DOI: 10.2340/00015555-1487.

17. Feijó ED, Nery ACS, Caiado FR, Prehis AM,Limongi RM. Extraconal cystic schwannoma mimicking an orbital dermoid cyst. Arq Bras Oftalmol. 2016;79(4):258-60. DI: 10.5935/0004-2749.20160073

18. Sim HS, Lee DG, Hwang JH, Kim KS, Lee SY. Peripheral osteoma on the medial eyebrow successfully extracted while preserving supratrochlear nerve. Arch Craniofac Surg. 2019;20(6):421-24. DOI: 10.7181/acfs.2019.00563.

19. Maciel VS, Marback EF, Sé DC, Marback RL. Neurilemoma benigno do nervo supraorbitário.Rev Bras Oftalmol. 2001;60(1):66-9.

20. Dulani S, Diagavane S, Lele S, Gaurkhede H. A Bilobed Schwannoma in Roof of Orbit: A Rare Case Report. Case Reports in Ophthalmological Medicine. 2012:1-4. DOI: $10.1155 / 2012 / 139241$

21. Chawda SJ, Moseley IF. Computed tomography of orbital dermoids: a 20-year review. Clin Radiol.1999;54:821-25. DOI: 10.1016/S0009-9260(99)90686-4

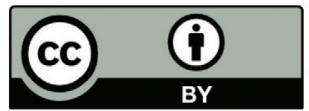

This work is licensed under a Creative Commons Attribution 